\title{
Physicochemical Meat Quality, Fatty Acid and Free Amino Acid Composition of Strip loin, Chuck Tender, and Eye of Round Produced by Different Age Groups of Hanwoo Cow
}

\author{
Soohyun Cho*, Sunmoon Kang, Geunho Kang, Pilnam Seong, Kyungmi Park, Sunsik Chang, \\ Seunghwan Lee, Youngmoo Cho, and Beomyoung Park \\ National Institute of Animal Science, Rural Development Administration, Suwon 441-706, Korea
}

\begin{abstract}
This study was performed to investigate the influence of age on the physicochemical properties of strip loin $(\mathrm{m}$. longissimus lumborum), chuck tender (m. supraspinatus), and eye of round (m. semitendinosus) of Hanwoo cows. Hanwoo cows ( $\mathrm{n}=126 ; 24-194 \mathrm{mon}$; live weight, 270-500 kg) were slaughtered and three muscles were obtained according to 3 age groups (G1, < 5 years old; G2, 6-8 years old; G3, > 9 years old). The chuck tender had significantly higher protein contents in G3 than in G1 or G2 ( $p<0.05)$. For strip loin and chuck tender, G1 had significantly higher intramuscular fat contents than G3 $(p<0.05)$. The chuck tender had significantly higher $\mathrm{b}^{*}$ (yellowness) values for $\mathrm{G} 2$ than for $\mathrm{G} 1(\mathrm{p}<0.05)$. The three muscles had significantly higher cooking loss (\%) and lower WHC (\%) in G3 than in G1 or G2 $(p<0.05)$. WBS values of strip loin were significantly higher in $\mathrm{G} 3$ than in the other groups $(p<0.05)$. The three muscles had higher $\mathrm{C} 18: \ln 9$ in $\mathrm{G} 1$ than that in the other groups. The total content of saturated fatty acids was significantly higher in G3 than in G1 for all 3 muscles $(p<0.05)$. Regarding free amino acid contents, $\mathrm{G} 1$ had significantly higher contents of threonine, alanine, valine, methionine, phenylalanine, leucine, and lysine in the strip loin than $\mathrm{G} 2$ or G3 $(p<0.05)$. In conclusion, young cow beef were higher in the WHC, intramuscular fat and free amino acids contents, whereas old cow beef had higher cooking loss and WBS $(p<0.05)$.
\end{abstract}

Key words: Hanwoo cow, meat quality, fatty acids, free amino acids

\section{Introduction}

In 2012, approximately 842,771 heads of Hanwoo cattle were slaughtered in Korea. Mature Hanwoo cows represent a significant meat source for the Korean beef industry and they accounted for 51.8\% (436,977 heads) of the total beef cattle slaughtered in Korea (KAPE, 2012). Several factors influence the quality attributes of mature cows in the beef cattle group. Beef from physiologically old carcasses is generally less tender than that from young animals because of the chemical nature of muscle-fiber fragmentation and connective tissue collagen (i.e., type and degree of cross-linking) (Lawrie, 1998; Shorthose and Harris, 1990). Furthermore, the oxidative stability of meat may be affected by animal age. Lipid oxidation that occurs in post-mortem meat can be a major

\footnotetext{
*Corresponding author: Soohyun Cho, Animal Products Research and Development Division, National Institute of Animal Science, Rural Development Administration, Suwon 441-706, Korea. Tel: 82-31-290-1703, Fax: 82-31-290-1697, E-mail: shc0915@korea.kr
}

impediment to the successful marketing of cow meat (Xiong et al., 2007); the discoloration resulting from myoglobin oxidation could negatively affect the utility of the meat. Boccard et al. (1979) reported that increased chronological age in cattle resulted in dark-colored lean meat. Further, Stadtman (2006) reported that increasing age increased the susceptibility of muscle cells to oxidizing agents in small animals and humans because agerelated loss in redox potential could predispose postmortem muscles to higher rates of oxidation in old cows. A limited number of studies have been conducted to investigate the possible effects of animal age on the postmortem progression of proteolysis in relation to meat tenderness (Huff-Lonergan et al., 1995; Koohmaraie et al., 1984; Parrish, 1981). These studies showed a reduced rate of post-mortem myofibrillar protein degradation in muscle from physiologically mature (E maturity) cattle compared to muscle from young (A maturity) carcasses and the variability in beef tenderness resulted from the different physiological ages of cattle. The lack of literature showing the potential differences in post-mortem 
muscles from mature cows of various ages, coupled with the abundant supply of mature cows as a meat source in the market, indicates the need to further explore factors that may be responsible for the overall quality of postmortem meat. The objective of the present study was to investigate the physicochemical meat quality and compositional properties of strip loin ( $m$. lumborum), chuck tender ( $m$. supraspinatus), and eye of round ( $m$. semitendinosus) from different age groups of Hanwoo cow.

\section{Material and Methods}

\section{Sample preparation}

Hanwoo cows ( $n=126$; age, 24-194 mon old; live weight, $270-500 \mathrm{~kg}$ ) were reared at the Daekwanryung experimental station of National Institute of Animal Science (NIAS) of RDA. Animals were transported to the NIAS abattoir, Suwon, Korea, and fasted for approximately $12 \mathrm{~h}$ but with access to water prior to slaughter. The left side of each carcass was deboned and trimmed to domestic fabrication. Strip loin ( $m$. longissimus dorsi), chuck tender ( $m$. supraspinatus), and eye of round ( $m$. semitendinosus) were separated, vacuum packaged, and stored at $2^{\circ} \mathrm{C}$ for $7 \mathrm{~d}$. All beef samples were divided into 3 age groups: Group 1 (G1), < 5 years old; Group 2 (G2), 6-8 years old; Group 3 (G3) > 9 years old. The means of carcass weights for each age group were G1 372, G2 365, G3 $367 \mathrm{~kg}$, respectively. Each beef sample was vacuumpackaged and stored at $-20^{\circ} \mathrm{C}$ until the analysis was conducted.

\section{Chemical and meat quality analysis procedures}

Protein, fat, moisture, and collagen content were analyzed using the Food Scan ${ }^{\mathrm{TM}}$ Lab 78810 (Foss Tecator Co., Ltd., DK), according to the method of the Association of Official Analytical Chemists (AOAC, 2006). Water-holding capacity (WHC) was measured using the method of Ryoichi et al. (1993). Color values on a freshly cut surface of the Warner-Bratzler shear force (WBSF) block were measured using a CR-301 chroma meter (Minolta Co., Osaka, Japan) for CIE standard lightness (L*), redness $\left(a^{*}\right)$, and yellowness $\left(b^{*}\right)$ after a 30 min blooming at $2^{\circ} \mathrm{C}$ (CIE, 1986). The cooking loss (\%) was calculated as the percent of weight change during cooking for the WBS measurement. For cooking loss determination, the samples were freshly cut into blocks $(50 \times 50 \times 25 \mathrm{~mm})$ and weighed (initial weight). The individual meat blocks were placed in polyvinylchloride film bag and cooked at $80^{\circ} \mathrm{C}$ for $40 \mathrm{~min}$ in a water-bath (Waterbath BS-21. Jeiotech
Co., Korea). The samples were removed from the waterbath, cooled in cold water, and weighed. The cooking loss was expressed as a percentage of the initial sample weight (Honikel, 1998). WBSF was measured on cooked steaks ( $25 \mathrm{~mm}$ thick) according to the method of Wheeler et al., (2000) using an Instron Universal Testing Machine (Model 5543, UK).

\section{Fatty acids analysis}

Total lipids of beef samples were extracted by using chloroform-methanol $(2: 1, \mathrm{v} / \mathrm{v})$ according to the procedure of Folch et al. (1957). An aliquot of total lipid extract was methylated as described by Morrison and Smith (1964). Fatty acid methyl esters were analyzed by a gas chromatograph (Varian 3800) fitted with a fused silica capillary column, omegawax $205(30 \mathrm{~m} \times 0.32 \mathrm{~mm} \mathrm{I} \cdot \mathrm{D}$, $0.25 \mu \mathrm{m}$ film thickness). The injection port was at $250^{\circ} \mathrm{C}$ and the detector was maintained at $300^{\circ} \mathrm{C}$. Results were expressed as percentages based on the total peak area.

\section{Free amino acids analysis}

The free amino acid contents in beef sample were analyzed using a RP-HPLC 1200 system (Agilent Technologies Inc., USA) equipped with a diode array detector (DAD). HPLC conditions for free amino acids followed as described by Woodward and Henderson (2007). A Rapid Resolution HT Eclipse XDBC18 column (4.6 mm $\times 150$ mm column packed with $5 \mu \mathrm{m}$ particles Agilent Technologies Inc., USA) was used for separation of amino acids. Two hundred microlitres of the supernatant were derivatized with OPA for the primary amino acids and FMOC for the secondary amino acids; furthermore a $0.4 \mathrm{~N}$ borate buffer was used. Briefly, OPA-derivatized amino acids were monitored at $338 \mathrm{~nm}$ and FMOC-derivatized amino acids were monitored at $262 \mathrm{~nm}$. The column temperature at $40^{\circ} \mathrm{C}$; flow rate was $2 \mathrm{~mL} / \mathrm{min}$, using a gradient between two solvents. Solvent A was $10 \mathrm{mM} \mathrm{Na}_{2} \mathrm{HPO}_{4}$ : $10 \mathrm{mM}$ $\mathrm{Na}_{2} \mathrm{~B}_{4} \mathrm{O}_{7}: 0.5 \mathrm{mM} \mathrm{NaN}_{3}$ at $\mathrm{pH} 8.2$ and Solvent $\mathrm{B}$ was acetonitrile: methanol: water $(45: 45: 10 \mathrm{v} / \mathrm{v})$. For the calibration curves 17 primary amino acids, plus 4 extended amino acids are combined with fixed amounts of internal standards and final concentration of standard solution were 90, 225 and $900 \mathrm{pM}$. The primary amino acids were quantified by using external standard procedures or by using norvaline as an internal standard and the secondary amino acids were Extraction Methods and Free Amino Acids 371 quantified using sarcosine as an internal standard. Individual free amino acid values were expressed as $\mu \mathrm{mol} / \mathrm{g}$. 


\section{Statistical Analysis}

Each animal within the same slaughtered age group was treated as a replicate. Data were analyzed by the Student-Newman-Keuls' multiple comparison using the General Linear Model Procedure of the SAS program (2005). The significance level was set at $p<0.05$.

\section{Results and Discussion}

\section{Chemical composition}

The moisture, protein, fat, and collagen contents of the strip loin, chuck tender and eye of round muscles from Hanwoo cows are shown in Table 1. No significant differences were observed in protein contents among the age groups for strip loin and eye of round muscles; however, chuck tender muscles had significantly higher protein contents in G3 than in G1 and G2 $(p<0.05)$. The moisture contents were not significantly different among the 3 age groups for strip loin, chuck tender, and eye of round muscles $(p>0.05)$. For strip loin and chuck tender muscles, G1 showed significantly higher intramuscular fat content than that in $\mathrm{G} 3(p<0.05)$.

Visible intramuscular fat (IMF) or marbling is an important meat characteristic that is appreciated by the consumer because of its positive effects on taste, juiciness, and tenderness (Platter et al., 2005). Galli et al. (2008) reported that 12-year-old Hereford cows had the least amount of intramuscular fat in 4 age groups: 3, 4-5, 6-8, and 12 years. Reagan et al. (1976) showed different results in a study of 3 age categories (9-34, 44-96, and 119-323 months). No differences were observed in intramuscular fat content among the maturity classes and only moisture content differed between the groups. Pflanzer and de Felício (2011) found that a high and negative correlation coefficient of $-0.92(p<0.05)$ between moisture and fat contents. In the present study, the young maturity group had a higher $(p<0.05)$ intramuscular fat contents than that in the older maturity group. This could be due to Korean consumers preferred young Hanwoo cows $(<5$ years old) to old cows in the beef market and most young cows were fattened for 6-12 mon at the farm before slaughter. However, no significant differences were observed in collagen contents among the 3 age groups $(p>0.05)$ (Table 1).

\section{Meat quality}

Color is the first quality attribute that influences a consumer's purchasing intent (Risvik, 1994), while toughness is the attribute that will determine whether a consumer will re-purchase the product. Regarding meat color, $\mathrm{L}^{*}$ and $\mathrm{a}^{*}$ values of strip loin, chuck tender, and eye of round muscles were not significantly different among the 3 age groups; however, chuck tender muscles had significantly lower $\mathrm{b}^{*}$ values for $\mathrm{G} 2$ than for G1 $(p<0.05)$ (Table $2)$. Meat color $\left(a^{*}\right)$ values increased as the age increased from 3 to 15 mon of young Qinchuan cattle in China ( $\mathrm{Li}$ et al., 2011). Xiong et al. (2007) reported that there were no significant differences between the 2-4, 6-8, and 10-12 year age groups for raw semitendinosus (ST) or raw semimembranosus (SM) patties for any of the surface color parameters (CIE L*, $a^{*}$, and $\left.b^{*}\right)$. The 3 muscles had significantly higher cooking loss (\%) and lower WHC (\%) in G3 than in G1 and G2 $(p<0.05)$ (Table 2). Regarding WBS, values for strip loin muscles were significantly higher in G3 than in the other groups ( $p<0.05$ ), but chuck

Table 1. Chemical compositions and collagen contents of striploin, chuck tender and eye of round by different age groups of Hanwoo cows

\begin{tabular}{|c|c|c|c|c|c|}
\hline Cut & Age group* & Moisture (\%) & Protein (\%) & Fat (\%) & Collagen (\%) \\
\hline \multicolumn{6}{|l|}{ Striploin } \\
\hline & 1 & $62.42 \pm 0.65^{* *}$ & $19.63 \pm 0.19$ & $13.88 \pm 0.55^{\mathrm{a}}$ & $1.87 \pm 0.04$ \\
\hline & 2 & $63.79 \pm 0.47$ & $20.17 \pm 0.13$ & $12.17 \pm 0.50^{\mathrm{b}}$ & $1.87 \pm 0.03$ \\
\hline & 3 & $63.59 \pm 0.72$ & $19.88 \pm 0.24$ & $11.39 \pm 0.52^{b}$ & $1.85 \pm 0.04$ \\
\hline \multicolumn{6}{|c|}{ Chuck tender } \\
\hline & 1 & $68.15 \pm 0.43$ & $19.69 \pm 0.10^{b}$ & $8.66 \pm 0.36^{\mathrm{a}}$ & $1.88 \pm 0.04$ \\
\hline & 2 & $67.87 \pm 0.36$ & $19.68 \pm 0.10^{b}$ & $8.40 \pm 0.34^{\mathrm{a}}$ & $1.80 \pm 0.03$ \\
\hline & 3 & $69.20 \pm 0.30$ & $20.10 \pm 0.13^{\mathrm{a}}$ & $6.92 \pm 0.33^{b}$ & $1.88 \pm 0.04$ \\
\hline \multicolumn{6}{|c|}{ Eye of round } \\
\hline & 1 & $70.42 \pm 0.48$ & $21.06 \pm 0.16$ & $5.64 \pm 0.48$ & $1.83 \pm 0.02$ \\
\hline & 2 & $69.64 \pm 0.38$ & $20.80 \pm 0.09$ & $5.87 \pm 0.30$ & $1.81 \pm 0.03$ \\
\hline & 3 & $69.65 \pm 0.48$ & $20.89 \pm 0.16$ & $5.89 \pm 0.47$ & $1.86 \pm 0.04$ \\
\hline
\end{tabular}

*Group 1(G1), < 5 years old; Group 2 (G2), 6-8 years old; Group 3(G3) > 9 years old.

**Mean \pm standard error.

${ }^{a-b}$ Means in the same column within the same category with different letters are significantly different $(p<0.05)$. 
Table 2. CIE meat color $\left(L^{*}, a^{*}, b^{*}\right)$, cooking loss (CL, \%), sarcomere length (SL, $\left.\mu \mathrm{m}\right)$, Warner-Bratzler shear force (WBS, kg) and water holding capacity (WHC, \%) of striploin, chuck tender and eye of round by different age groups of Hanwoo cows

\begin{tabular}{|c|c|c|c|c|c|c|c|c|}
\hline \multirow{2}{*}{ Cut } & \multirow{2}{*}{ Age group* } & \multicolumn{3}{|c|}{ CIE } & \multirow{2}{*}{ CL (\%) } & \multirow{2}{*}{ WHC (\%) } & \multirow{2}{*}{ WBS (kg) } & \multirow{2}{*}{$\mathrm{SL}(\mu \mathrm{m})$} \\
\hline & & $\mathrm{L}^{*}$ & $\mathrm{a}^{*}$ & $\mathrm{~b}^{*}$ & & & & \\
\hline \multicolumn{9}{|c|}{ Striploin } \\
\hline & 1 & $33.96 \pm 0.47^{* *}$ & $19.88 \pm 0.48$ & $9.07 \pm 0.33$ & $23.65 \pm 0.43^{\mathrm{c}}$ & $55.34 \pm 0.34^{\mathrm{a}}$ & $3.99 \pm 0.12^{\mathrm{b}}$ & $2.48 \pm 0.03$ \\
\hline & 2 & $34.33 \pm 0.48$ & $19.44 \pm 0.35$ & $8.86 \pm 0.26$ & $25.50 \pm 0.46^{\mathrm{b}}$ & $54.54 \pm 0.30^{\mathrm{a}}$ & $3.85 \pm 0.11^{\mathrm{b}}$ & $2.49 \pm 0.02$ \\
\hline & 3 & $33.30 \pm 0.64$ & $18.97 \pm 0.42$ & $9.82 \pm 0.19$ & $27.17 \pm 0.52^{\mathrm{a}}$ & $52.54 \pm 0.37^{\mathrm{b}}$ & $4.62 \pm 0.13^{\mathrm{a}}$ & $2.54 \pm 0.02$ \\
\hline \multicolumn{9}{|c|}{ Chuck tender } \\
\hline & 1 & $35.12 \pm 0.52$ & $20.88 \pm 0.44$ & $9.94 \pm 0.29^{\mathrm{a}}$ & $26.54 \pm 0.57^{\mathrm{b}}$ & $54.94 \pm 0.27^{\mathrm{a}}$ & $5.03 \pm 0.18$ & $2.63 \pm 0.03^{\mathrm{a}}$ \\
\hline & 2 & $34.55 \pm 0.41$ & $19.85 \pm 0.29$ & $8.98 \pm 0.23^{b}$ & $27.23 \pm 0.53^{\mathrm{b}}$ & $53.79 \pm 0.40^{\mathrm{b}}$ & $4.73 \pm 0.11$ & $2.55 \pm 0.02^{\mathrm{b}}$ \\
\hline & 3 & $33.78 \pm 0.48$ & $20.41 \pm 0.37$ & $9.70 \pm 0.17^{\mathrm{ab}}$ & $29.24 \pm 0.67^{\mathrm{a}}$ & $51.35 \pm 0.49^{\mathrm{c}}$ & $5.24 \pm 0.15$ & $2.52 \pm 0.03^{\mathrm{b}}$ \\
\hline \multicolumn{9}{|c|}{ Eye of round } \\
\hline & 1 & $34.97 \pm 0.46$ & $20.88 \pm 0.48$ & $10.03 \pm 0.36$ & $26.93 \pm 0.53^{\mathrm{b}}$ & $54.77 \pm 0.29^{\mathrm{a}}$ & $4.97 \pm 0.15$ & $2.91 \pm 0.03$ \\
\hline & 2 & $34.71 \pm 0.45$ & $19.50 \pm 0.37$ & $9.21 \pm 0.28$ & $26.97 \pm 0.49^{b}$ & $53.79 \pm 0.45^{\mathrm{a}}$ & $4.75 \pm 0.11$ & $2.90 \pm 0.03$ \\
\hline & 3 & $33.86 \pm 0.45$ & $19.51 \pm 0.45$ & $9.90 \pm 0.24$ & $28.96 \pm 0.58^{\mathrm{a}}$ & $52.43 \pm 0.39^{\mathrm{b}}$ & $5.20 \pm 0.20$ & $2.84 \pm 0.05$ \\
\hline
\end{tabular}

*Group 1(G1), < 5 years old; Group 2 (G2), 6-8 years old; Group 3(G3) > 9 years old.

**Mean \pm standard error.

${ }^{a-c}$ Means in the same column within the same category with different letters are significantly different $(p<0.05)$.

tender and eye of round muscles showed no significant differences in WBS values among the 3 groups $(p>0.05)$ (Table 2). The sarcomere length (SL) was significantly longer for G1 of chuck tender muscle than for the other groups $(p<0.05)$, and there were no significant differences in strip loin and eye of round muscles. The sarcomere was the repeating structural unit of the myofibril and also the basic unit of the muscle's contraction-relaxation cycle occurred. Although the influences of the sarcomere length on the tenderness by different age groups was need to further study, Pflanzer and de Felício (2011) reported that sarcomere length was not affected $(p>0.05)$ by maturity. Several endogenous muscle enzyme systems with cathepsins and calpains were reported in the post-mortem tenderization of meat (Goll et al., 1983; Rowe et al., 2004). Huff-Lonergan et al. (1995) postulated that LD samples from old cattle probably contained higher calpastatin activity that inhibited calpain-mediated protein degradation in post-mortem beef. Xiong et al. (2007) postulated that older cows exhibited increased toughness because they probably had reduced calpain activity in muscles with greater oxidative stress compared to younger cattle. During post-mortem storage of beef muscles, the degradation of myofibrillar and cytoskeletal proteins depends on muscle type and animal age. Changes of titin T1 in the fraction of washed myofibrillar proteins observed on SDS-PAGE were small. Further pronounced changes occurred in the $30-\mathrm{kDa}$ fraction, i.e., the Tn-T degradation product. The appearance was slower in cow muscles than in heifer and calf muscles (Kolczak et al., 2003).

\section{Fatty acid composition}

The fatty acid compositions (\%) of strip loin, chuck tender, and eye of round muscles are shown in Tables 3-5. The strip loin muscles had significantly higher contents of C16:0, and eye of round muscles had significantly higher contents of C18:0 in G3 than in G1. The total contents of saturated fatty acids were significantly higher in

Table 3. Fatty acid compositions (\%) of striploin by different age groups of Hanwoo cows

\begin{tabular}{cccc}
\hline \hline Fatty acids & \multicolumn{3}{c}{ Age groups* } \\
\cline { 2 - 4 }$(\%)$ & 1 & 2 & 3 \\
\hline C14:0 & $2.90 \pm 0.08^{* *}$ & $3.08 \pm 0.09$ & $3.02 \pm 0.10$ \\
C16:0 & $28.04 \pm 0.40^{\mathrm{b}}$ & $29.28 \pm 0.35^{\mathrm{a}}$ & $29.69 \pm 0.41^{\mathrm{a}}$ \\
C18:0 & $11.04 \pm 0.27$ & $11.11 \pm 0.32$ & $11.37 \pm 0.46$ \\
$\mathrm{C} 16: 1 \mathrm{n} 7$ & $5.04 \pm 0.18$ & $5.16 \pm 0.15$ & $4.84 \pm 0.23$ \\
C18:1n7 & $0.51 \pm 0.04$ & $0.44 \pm 0.03$ & $0.40 \pm 0.04$ \\
C18:1n9 & $50.26 \pm 0.50$ & $49.16 \pm 0.47$ & $48.86 \pm 0.73$ \\
C18:2n6 & $1.58 \pm 0.08$ & $1.46 \pm 0.08$ & $1.45 \pm 0.07$ \\
C18:3n3 & $0.04 \pm 0.00^{\mathrm{c}}$ & $0.09 \pm 0.01^{\mathrm{b}}$ & $0.13 \pm 0.02^{\mathrm{a}}$ \\
C18:3n6 & $0.02 \pm 0.00^{\mathrm{b}}$ & $0.03 \pm 0.00^{\mathrm{ab}}$ & $0.04 \pm 0.00^{\mathrm{a}}$ \\
C20:1n9 & $0.13 \pm 0.02$ & $0.10 \pm 0.01$ & $0.09 \pm 0.02$ \\
C20:4n6 & $0.08 \pm 0.01$ & $0.10 \pm 0.02$ & $0.11 \pm 0.02$ \\
SFA & $41.98 \pm 0.61^{\mathrm{b}}$ & $43.46 \pm 0.51^{\mathrm{ab}}$ & $44.08 \pm 0.74^{\mathrm{a}}$ \\
MUFA & $56.30 \pm 0.60^{\mathrm{a}}$ & $54.86 \pm 0.50^{\mathrm{ab}}$ & $54.19 \pm 0.79^{\mathrm{b}}$ \\
PUFA & $1.73 \pm 0.09$ & $1.68 \pm 0.09$ & $1.73 \pm 0.08$ \\
n3 & $0.04 \pm 0.00^{\mathrm{c}}$ & $0.09 \pm 0.01^{\mathrm{b}}$ & $0.13 \pm 0.02^{\mathrm{a}}$ \\
n6 & $1.68 \pm 0.09$ & $1.59 \pm 0.09$ & $1.60 \pm 0.08$ \\
\hline
\end{tabular}

*Group 1(G1), < 5 years old; Group 2 (G2), 6-8 years old; Group $3(\mathrm{G} 3)>9$ years old.

**Mean \pm standard error.

${ }^{\mathrm{a}-\mathrm{c}}$ Means in the same row within the same category with different letters are significantly different $(p<0.05)$. 
Table 4. Fatty acid compositions (\%) of chuck tender by different age groups of Hanwoo cows

\begin{tabular}{|c|c|c|c|}
\hline \multirow{2}{*}{$\begin{array}{c}\text { Fatty acids } \\
(\%)\end{array}$} & \multicolumn{3}{|c|}{ Age groups* } \\
\hline & 1 & 2 & 3 \\
\hline C14:0 & $2.22 \pm 0.07^{* *}$ & $2.37 \pm 0.07$ & $2.30 \pm 0.11$ \\
\hline C16:0 & $25.97 \pm 0.77$ & $27.06 \pm 0.36$ & $27.43 \pm 0.49$ \\
\hline C18:0 & $12.24 \pm 0.42$ & $13.10 \pm 0.28$ & $13.57 \pm 0.54$ \\
\hline $\mathrm{C} 16: \ln 7$ & $3.79 \pm 0.16$ & $3.82 \pm 0.12$ & $4.35 \pm 0.69$ \\
\hline $\mathrm{C} 18: \ln 7$ & $0.40 \pm 0.03^{\mathrm{a}}$ & $0.32 \pm 0.02^{\mathrm{b}}$ & $0.29 \pm 0.03^{b}$ \\
\hline C18:1n9 & $50.15 \pm 1.14$ & $49.01 \pm 0.63$ & $47.08 \pm 1.10$ \\
\hline C18:2n6 & $3.40 \pm 0.55$ & $3.33 \pm 0.45$ & $3.58 \pm 0.29$ \\
\hline C18:3n3 & $0.17 \pm 0.07$ & $0.14 \pm 0.01$ & $0.27 \pm 0.09$ \\
\hline C18:3n6 & $0.09 \pm 0.04$ & $0.04 \pm 0.00$ & $0.12 \pm 0.07$ \\
\hline C20:1n9 & $0.16 \pm 0.02$ & $0.13 \pm 0.01$ & $0.15 \pm 0.03$ \\
\hline $\mathrm{C} 20: 4 \mathrm{n} 6$ & $1.34 \pm 1.00$ & $0.69 \pm 0.17$ & $0.78 \pm 0.27$ \\
\hline SFA & $39.89 \pm 1.26^{\mathrm{b}}$ & $42.53 \pm 0.53^{\mathrm{ab}}$ & $43.30 \pm 0.86^{\mathrm{a}}$ \\
\hline MUFA & $52.93 \pm 1.69$ & $53.28 \pm 0.68$ & $51.87 \pm 1.12$ \\
\hline PUFA & $5.49 \pm 1.32$ & $4.19 \pm 0.49$ & $4.82 \pm 0.74$ \\
\hline n3 & $1.92 \pm 1.68$ & $0.14 \pm 0.01$ & $0.34 \pm 0.16$ \\
\hline n6 & $6.30 \pm 1.89$ & $4.05 \pm 0.49$ & $4.49 \pm 0.60$ \\
\hline
\end{tabular}

*Group 1(G1), < 5 years old; Group 2 (G2), 6-8 years old; Group $3(\mathrm{G} 3)>9$ years old.

** Mean \pm standard error.

${ }^{\mathrm{a}-\mathrm{b}}$ Means in the same row within the same category with different letters are significantly different $(p<0.05)$.

Table 5. Fatty acid compositions of eye of round by different age groups of Hanwoo cows

\begin{tabular}{|c|c|c|c|}
\hline \multirow{2}{*}{$\begin{array}{c}\text { Fatty acids } \\
(\%)\end{array}$} & \multicolumn{3}{|c|}{ Age groups* } \\
\hline & 1 & 2 & 3 \\
\hline C14:0 & $2.52 \pm 0.11 * *$ & $2.75 \pm 0.06$ & $2.55 \pm 0.13$ \\
\hline C16:0 & $28.22 \pm 0.46$ & $29.15 \pm 0.34$ & $29.62 \pm 0.42$ \\
\hline C18:0 & $9.88 \pm 0.40^{\mathrm{b}}$ & $10.93 \pm 0.27^{\mathrm{ab}}$ & $11.83 \pm 0.50^{\mathrm{a}}$ \\
\hline $\mathrm{C} 16: \ln 7$ & $5.76 \pm 0.26^{\mathrm{a}}$ & $5.28 \pm 0.21^{\mathrm{ab}}$ & $4.67 \pm 0.25^{\mathrm{b}}$ \\
\hline C18:1n7 & $0.63 \pm 0.05^{\mathrm{a}}$ & $0.48 \pm 0.03^{\mathrm{b}}$ & $0.42 \pm 0.04^{\mathrm{b}}$ \\
\hline C18:1n9 & $49.45 \pm 0.82$ & $48.66 \pm 0.47$ & $47.51 \pm 0.87$ \\
\hline $\mathrm{C} 18: 2 \mathrm{n} 6$ & $2.36 \pm 0.24$ & $2.00 \pm 0.12$ & $2.19 \pm 0.27$ \\
\hline C18:3n3 & $0.17 \pm 0.08$ & $0.12 \pm 0.01$ & $0.22 \pm 0.09$ \\
\hline C18:3n6 & $0.12 \pm 0.07$ & $0.04 \pm 0.00$ & $0.11 \pm 0.07$ \\
\hline C20:1n9 & $0.13 \pm 0.02$ & $0.10 \pm 0.01$ & $0.09 \pm 0.02$ \\
\hline $\mathrm{C} 20: 4 \mathrm{n} 6$ & $0.61 \pm 0.24$ & $0.48 \pm 0.07$ & $0.73 \pm 0.28$ \\
\hline SFA & $40.62 \pm 0.63^{b}$ & $42.82 \pm 0.49^{\mathrm{a}}$ & $44.00 \pm 0.61^{\mathrm{a}}$ \\
\hline MUFA & $55.98 \pm 0.98^{\mathrm{a}}$ & $54.54 \pm 0.48^{\mathrm{ab}}$ & $52.69 \pm 0.98^{\mathrm{b}}$ \\
\hline PUFA & $3.39 \pm 0.71$ & $2.64 \pm 0.18$ & $3.32 \pm 0.76$ \\
\hline n3 & $0.25 \pm 0.14$ & $0.12 \pm 0.01$ & $0.29 \pm 0.16$ \\
\hline n6 & $3.14 \pm 0.58$ & $2.52 \pm 0.18$ & $3.03 \pm 0.60$ \\
\hline
\end{tabular}

*Group 1(G1), < 5 years old; Group 2 (G2), 6-8 years old; Group 3 (G3) $>9$ years old.

** Mean \pm standard error.

${ }^{a-b}$ Means in the same row within the same category with different letters are significantly different $(p<0.05)$.

G3 than in G1 for all 3 muscles $(p<0.05)$. The chuck tender and eye of round muscles had significantly higher contents of $\mathrm{C} 18: \ln 7$ in $\mathrm{G} 1$ than in G3 $(p<0.05)$. The total content of monounsaturated fatty acids was significantly higher in G1 than in G3 for strip loin and eye of round muscles $(p<0.05)$. Fatty acid composition has an important effect on firmness or softness of the fat in meat, especially for the subcutaneous and intramuscular fat. The effect of fatty acids on firmness is a result of the different melting points of the fatty acids in meat. Unsaturated fatty acids with more than two double bonds are important in regulating the shelf life of meat (rancidity and color deterioration) because of their rapid oxidation and in flavor development during cooking (Wood et al., 2003). Although it has been suggested that dietary fatty acids influence tenderness and juiciness, these are more likely to be affected by the total amount of fatty acids rather than by individual ones. In very fat cattle, the fat is soft and oily mainly due to an increase in 18:1 relative to $18: 0$ and 16:0 (Leat, 1975). Wood (1984) recorded a value for 18:0 for $14.7 \%$ of total fatty acids in a young heifer and $2.7 \%$ in an 11-year-old fat steer. However, in the present study, no significant differences were observed in the contents of C18:0 among the 3 age groups, except in the eye of round muscle. Sensory-panel scores were negatively associated with total saturated fatty acids, mainly stearic and palmitic acids, which were the highest in grass-fed animals, and positively associated with total unsaturated fatty acids, mainly because of the high levels of oleic acid in grain-fed animals (Wood, 1984). In addition, different SFAs have been found to have different effects on the serum cholesterol concentrations, and stearic acid (18:0) was shown to have no effect on or even reduce serum cholesterol level.

\section{Free amino acids}

Feidt et al. (1996) reported that the final protein degradation products such as peptides and free amino acids were involved in the enzymatic reactions, and they played an important role in flavor development (Kato et al., 1989; Aristoy and Toldrá, 1995; Nishimura, 1998). In the comparison of the free amino acids contents among the 3 age groups of strip loin muscle, G1 had significantly higher contents of threonine, alanine, valine, methionine, phenylalanine, leucine, and lysine than those in G2 and G3 $(p<0.05)$ (Table 6). It had been reported that the degradation of myofibrillar proteins depends on animal age (Lonergan et al., 1995; Xiong et al., 2007). During postmortem storage of beef muscles, the muscle from old cattle less susceptible to degrade due to it contained higher calpastatin activity with greater oxidative stress compared to younger cattle. An increase in amino acids in beef during the ageing period has been elucidated in 
Table 6. Free amino acids (FAA) compositions of strip loin by different age groups of Hanwoo cows

\begin{tabular}{cccc}
\hline \hline \multirow{2}{*}{ FAA } & \multicolumn{3}{c}{ Age groups } \\
\cline { 2 - 4 } & 1 & 2 & 3 \\
\hline Glutamate & $0.75 \pm 0.02^{* *}$ & $0.71 \pm 0.03$ & $0.68 \pm 0.04$ \\
Asparagine & $0.10 \pm 0.01$ & $0.09 \pm 0.01$ & $0.11 \pm 0.01$ \\
Serine & $0.65 \pm 0.02$ & $0.60 \pm 0.03$ & $0.62 \pm 0.02$ \\
Glutamine & $4.66 \pm 0.17$ & $4.79 \pm 0.15$ & $4.75 \pm 0.18$ \\
Histidine & $0.36 \pm 0.01$ & $0.33 \pm 0.01$ & $0.34 \pm 0.01$ \\
Glycine & $0.40 \pm 0.05$ & $0.72 \pm 0.05$ & $0.88 \pm 0.05$ \\
Threoinine & $0.56 \pm 0.03^{\mathrm{a}}$ & $0.43 \pm 0.02^{\mathrm{b}}$ & $0.46 \pm 0.02^{\mathrm{b}}$ \\
Arginine & $0.60 \pm 0.03$ & $0.54 \pm 0.02$ & $0.55 \pm 0.02$ \\
Alanine & $15.89 \pm 0.37^{\mathrm{a}}$ & $13.68 \pm 0.28^{\mathrm{b}}$ & $13.76 \pm 0.33^{\mathrm{b}}$ \\
Tyrosine & $0.41 \pm 0.02$ & $0.35 \pm 0.01$ & $0.34 \pm 0.03$ \\
Cysteine & $0.09 \pm 0.01$ & $0.13 \pm 0.02$ & $0.12 \pm 0.02$ \\
Valine & $0.51 \pm 0.02^{\mathrm{a}}$ & $0.44 \pm 0.02^{\mathrm{b}}$ & $0.45 \pm 0.02^{\mathrm{ab}}$ \\
Methionine & $0.70 \pm 0.03^{\mathrm{a}}$ & $0.63 \pm 0.03^{\mathrm{b}}$ & $0.63 \pm 0.02^{\mathrm{b}}$ \\
Phenylalanine & $0.87 \pm 0.02^{\mathrm{a}}$ & $0.74 \pm 0.03^{\mathrm{b}}$ & $0.69 \pm 0.01^{\mathrm{b}}$ \\
Isoleucine & $0.93 \pm 0.01^{\mathrm{ab}}$ & $0.86 \pm 0.02^{\mathrm{b}}$ & $0.98 \pm 0.01^{\mathrm{a}}$ \\
Leucine & $0.66 \pm 0.02^{\mathrm{a}}$ & $0.54 \pm 0.01^{\mathrm{b}}$ & $0.55 \pm 0.01^{\mathrm{b}}$ \\
Lysine & $0.78 \pm 0.02^{\mathrm{a}}$ & $0.63 \pm 0.03^{\mathrm{b}}$ & $0.66 \pm 0.03^{\mathrm{b}}$ \\
Proline & $0.87 \pm 0.04$ & $0.98 \pm 0.05$ & $0.90 \pm 0.04$ \\
\hline
\end{tabular}

*Group 1(G1), < 5 years old; Group 2 (G2), 6-8 years old; Group 3 (G3) $>9$ years old.

**Meantstandard error.

${ }^{\mathrm{a}-\mathrm{b}}$ Means in the same row within the same category with different letters are significantly different $(p<0.05)$.

previous studies that showed that proteolysis contributes to the breakdown of myofibrillar protein and the action of calpains and cathepsins on major myofibrillar proteins, generating protein fragments and intermediate size polypeptides; furthermore, polypeptides and peptides generate free amino acids (Toldrá, 2006). An increase in particular amino acids caused by ageing was shown in previous studies. Field et al. (1971) found that large increases in alanine, glutamine, serine, valine, leucine, and lysine are obtained by ageing beef for $5 \mathrm{~d}$. Batzer et al. (1960) showed that amino acids participated as the precursors of the taste and flavor of cooked meat. The specific meat flavor could not develop with only one component; rather it was developed through the combination of many types of amino acids and sugars. The balance in the quantities of different peptides and amino acids from the breakdown of proteins was the key for palatability of meat. Feidt et al. (1996) reported that the contents of free amino acids and peptides degraded from meat protein were related to the cut and aging condition and that they increased with increasing numbers of aging days. The increase in peptides is because of the action of proteinases such as calpains and cathepsins, while the increase of free amino acids is because of the action of aminopeptidases, which are enzymes whose optimal $\mathrm{pH}$ is close to neutral (Flores et al.,
1993, 1996).

\section{Acknowledgements}

This study was supported by grants of PJ907000 from National Institute of Animal Science, Rural Development Administration, 2011-2012.

\section{References}

1. AOAC (2006) Official Methods of Analysis. 15th ed., Association of Official Analytical Chemists, Washington, D.C., 210-219.

2. Aristoy, M. C. and Toldrá, F. (1995) Isolation of flavor peptides from raw pork meat and dry-cured ham. In: Food flavors: generation, analysis and process influence. Charalambous, G. Elsevier Science, BV, Amsterdam, pp. 1323-1344.

3. Batzer, O. F., Santoro, A. T., Tan, M. C., Landmann, W. A., and Schweigert, B. S. (1960) Precursors of beef flavor. $J$. Agric. Food Chem. 8, 498.

4. Boccard, R., Naude, R. T., Chronje, D. E., Smit, M. C., Venter, H. J., and Rossouw, E. J. (1979) The influence of age, sex, breed of cattle on their muscle characteristics. Meat Sci. 3, 261-265.

5. CIE (1986) Colorimetry. $2^{\text {nd }}$ ed. Commision Internationale de Leclairagel' Eclairage, Publication CIE No. 15.2. Vienna

6. Feidt, C., Petit, A., Bruas, R. F., and Brun, B. J. (1996) Release of free amino acids during ageing in bovine meat. Meat Sci. 44, 19-25.

7. Field, R. A., Riley, M. L., and Chang, Y. O. (1971) Free amino acid changes in different aged bovine muscles and their relationship to shear values. J. Food Sci. 36, 611-612.

8. Folch, J., Lees, M., and Stanley, G. H. S. (1957) A simple method for the isolation and purification of total lipid from animal tissue. J. Biol. Chem. 226, 497-500.

9. Galli, I., Teira, G., Perlo, F., Bonato, p., Tisocco, O., Monje, A., and Vittone, S. (2008) Animal performance and meat quality in cull cows with early weaned calves in Argenitina. Meat Sci. 79, 521-528.

10. Goll, D. E., Otsuka, Y., Nagainis, P. A., Shannon, J. D., Sathe, S. K., and Muguruma, M. (1983) Role of muscle proteases in maintenance of muscle intergrity and mass. J. Food Biochem. 7, 137-177.

11. Honikel, K. O. (1998) Reference methods for the assessment of physical characteristics of meat. Meat Sci. 49, 447-457.

12. Huff-Lonergan, E., Parrish, F. C., Jr., and Robson, R. M. (1995) Effects of postmortem aging time, animal age, and sex on degradation of titin and nebulin in bovine longissimus muscle. J. Anim. Sci. 73, 1064-1073.

13. KAPE (Korea Institute for Animal Product's Quality Evaluation). (2012) Animal Products Grading Statistical Yearbook, 6th ed, Vision Publishing, Gunpo, Korea.

14. Kato, H., Rhuc, M. R., and Nishimura, T. (1989) Role of free amino acids and peptides in food tastc. In R. Teranishi, R. G. Buttery, and F. Shahidi, Flavor chemisty. Trends and devel- 
opment (pp. 158-174). Washington: ACS Symposium Series 388 , ACS.

15. Kolczak, T., Pospieh, E., Palka, K., and Ladki, J. (2003) Changes of myofibrillar and centrifugal drip proteins and shear force of psoas major and semitendinosus muscles from calves, heifers and cows during post-mortem ageing. Meat Sci. 62, 69-75.

16. Koohmaraie, M., Kennick, W. H., Elgasim, E. A., and Anglemier, A. F. (1984) Effects of postmortem storage on muscle protein degradation: Analysis by SDS-polyacrylamide gel electrophoresis. J. Food Sci. 49, 292-293.

17. Lawrie, R. A. (1998) Lawrie's Meat Science, 6th ed, Cambridge, UK: Woodhead Publishing, Ltd., pp. 336.

18. Leat, W. M. F. (1975) Fatty acid composition of adipose tissue of Jersey cattle during growth and development. J. Agric. Sci. 85, 551-558.

19. Li, L. Q., Tian, W. Q., and Zan, K. S. (2011) Effects of age on quality of beef from Qinchuan Cattle Carcass. China Agric. Sci. 10, 1765-1771.

20. Morrison, W. R. and Smith, L, M. (1964) Preparation of fatty acid methylesters and dimethylacetals from lipid with boron fluoridemethanol. J. Lipid Resour. 5, 600-608.

21. Nishimura, T. (1998) Mechanism involved in the improvement of meat taste during postmortem aging. Food Sci. Technol. Int. Tokyo 4, 241-249.

22. Parrish, F. C. (1981) Relationship between beef carcass quality indicators and palatability. In proceedings of the National Beef Grading Conference. Iowa State University, Ames, IA.

23. Pflanzer, S. B. and de Felício, P. E. (2011) Moisture and fat content, marbling level and color of boneless rib cut from Nellore steers varying in maturity and fatness. Meat Sci. 87, 7-11.

24. Platter, W. J., Tatum, J. K., Belk, K. E., Koontz, S. R., Chapman, P. L., and Smith, G, C. (2005) Effects of marbling and shear force on consumer's willingness to pay for beef strip loin steaks. J. Anim. Sci. 83, 890-899.

25. Reagan, J. O., Carpenter, Z. L., and Smith, G. C. (1976) Agerelated traits affecting the tenderness of the bovine Longissimus muscle. J. Anim. Sci. 43, 1198-1205.
26. Risvik, E. (1994) Sensory properties and preference. Meat Sci. 36, 67-77.

27. Rowe, L. J., Maddock, K. R., Lonergan, S. M., and HuffLonergan, E. (2004) Oxidative environments decrease tenderization of beef steaks through inactivation of $\mathrm{m}$-calpain. J. Anim.Sci. 82, 3254-3266.

28. Ryoichi, S., Degychi, T., and Nagata, Y. (1993) Effectiveness of the filter paper press methods for determining the water holding capacity of meat. Fleischwirtsch 73, 1399

29. SAS. (2005) SAS/STAT Software for PC. Release 6.11, SAS Institute Inc., Cary, NC, USA.

30. Shorthose, W. R. and Harris, P. V. (1990) Effect of animal age on the tenderness of selected beef muscles. J. Food Sci. 55, $1-8$.

31. Stadtman, E. R. (2006) Protein oxidation and aging. Free Rad. Res. 40, 1250-1258.

32. Toldrá, F. (2006) The role of muscle enzymes in dry-cured meat products with different drying conditions, Trends Food Sci. Technol. 17, 164-168.

33. Wheeler, T. L., Shackelford, S. D., and Koohmaraie. M. (2000) Variation in proteolysis, sarcomere length, collagen content, and tenderness among major pork muscles. J. Anim. Sci. 78, 958-965

34. Wood, J. D. (1984) Fat deposition and the quality of fat tissue in meat animals. In: Fats in animal nutrition. Wiseman, J. (ed) Butterworths, London, pp. 407-435.

35. Wood, J. D., Richardson, R. I., Nute, G. R., Fisher, A. V., Campo, M. M., Kasapidou, E., Kasapidou, P. R., and Enser, S. M. (2003) Effect of fatty acids on meat quality: A review. Meat Sci. 66, 21-32.

36. Woodward, C. and Henderson, J. W. (2007) High-speed amino acid analysis on $1.8 \mu \mathrm{m}$ Reversed-Phase (RP) columns. Agilent technologies, Pharmaceuticals Food 1-13.

37. Xiong, Y. L., Mullins, O. E., Stika, Chen, J., Blanchard, S. P., and Moody, W. G. (2007) Tenderness and oxidative stability of post-mortem muscles from mature cows of various ages. Meat Sci. 77, 105-113.

(Received 2013.9.23/Revised 2013.10.21/Accepted 2013.10.28) 